\title{
Activity of enzymatic antioxidants in periodontitis: A systematic overview of the literature
}

\section{Aktywność antyoksydantów enzymatycznych w zapaleniach przyzębia - systematyczny przegląd piśmiennictwa}

\author{
Joanna Toczewska ${ }^{B-D}$, Tomasz Konopka ${ }^{A, E, F}$ \\ Department of Periodontology, Wroclaw Medical University, Poland \\ A - research concept and design; $B$ - collection and/or assembly of data; $C$ - data analysis and interpretation; \\ $D$ - writing the article; $E$ - critical revision of the article; $F$ - final approval of the article
}

Address for correspondence

Joanna Toczewska

E-mail: joanna.toczewska@umed.wroc.pl

Funding sources

None declared

Conflict of interest

None declared

Received on July 16, 2019

Reviewed on September 2, 2019

Accepted on September 5, 2019

Published online on December 30, 2019

Cite as

Toczewska J, Konopka T. Activity of enzymatic antioxidants in periodontitis: A systematic overview of the literature. Dent Med Probl. 2019;56(4):419-426. doi:10.17219/dmp/112151

D0I

$10.17219 / \mathrm{dmp} / 112151$

Copyright

(c) 2019 by Wroclaw Medical University

This is an article distributed under the terms of the

Creative Commons Attribution 3.0 Unported License (CC BY 3.0)

(https://creativecommons.org/licenses/by/3.0/)

\begin{abstract}
Periodontitis is initiated by a bacterial infection and an abnormal immune response of the host resulting in the formation of dysbiotic subgingival biofilm and the progressive destruction of the attachment apparatus of the teeth. It is believed that disturbances in the local and/or general indicators of oxidative stress are one of the mechanisms in the etiopathogenesis of periodontitis. Organisms using oxygen in their metabolic processes are equipped with mechanisms that protect against the activity of oxygen-free radicals. They are commonly referred to as 'the antioxidative barrier of the system'. The main enzymatic antioxidants which have been widely studied in the gingival fluid, saliva and blood serum of patients with periodontitis are superoxide dismutase (SOD), glutathione peroxidase (GPX) and catalase (CAT).

The aim of this systematic overview of the literature was to present the current research on the activity of these antioxidant enzymes in the gingival fluid, saliva and blood serum of patients with periodontitis.

Findings on the activity of these enzymes in the gingival tissue, gingival fluid, saliva, and blood serum in the course of the types of periodontitis that have been classified so far (chronic or aggressive) are quite disparate. Their activity in the gingival tissue was usually elevated, whereas in the saliva it was reduced. These differences may have resulted from the different methods of biochemically assessing their activity, and may have not reflected the stage and/or the risk of progression of periodontitis.
\end{abstract}

Key words: periodontitis, oxidative stress, antioxidants, superoxide dismutase

Słowa kluczowe: zapalenie przyzębia, stres oksydacyjny, antyoksydanty, dysmutaza ponadtlenkowa 


\section{Introduction}

The existence of reactive oxygen species (ROS) is integrally connected to the metabolism of all aerobic organisms. In physiological conditions, ROS act as the mediators and regulators of many biochemical processes. However, a disturbance in the balance between the processes of production and degradation of ROS leads to damage to cellular components. Oxidative stress can be defined as a situation in which a disturbance in this oxidoreductive balance leads to a temporary or chronic increase in the production of ROS and, as a consequence, to a disturbance in the cellular metabolism and the degradation of cellular components. ${ }^{1}$ Organisms using oxygen in metabolic processes are equipped with mechanisms that protect against the activity of oxygen-free radicals. ${ }^{2-4}$ Enzymatic antioxidants include superoxide dismutase (SOD; EC (Enzyme Commission number) 1.15.1.1), glutathione peroxidase (GPx; EC 1.11.1.9) and catalase (CAT; EC 1.11.1.6), among others.

Periodontitis is a multifactorial disease which leads to progressive periodontal tissue destruction and is connected with dysbiotic biofilm. Pathogenic biofilm is a prerequisite for the development of periodontitis, but it cannot initiate the disease on its own. It has been proven that periodontitis may be related to the local and/or systemic indicators of oxidative stress. ${ }^{5}$ After the immune reaction is initiated by the biofilm, neutrophils are the cells that most often occur in the gingival fluid of the periodontal pocket. In one study, polymorphonuclear leukocytes (PMNs) isolated from patients with early periodontitis produced much more superoxide anion radical $\left(\mathrm{O}_{\left.2^{\bullet^{-}}\right)}\right)$than the cells from the control group. ${ }^{6}$ During the 'respiratory burst', catalyzed by nicotinamide adenine dinucleotide phosphate (NADPH) oxidase, hyperactive neutrophils produce large amounts of $\mathrm{O}_{2} \cdot \bullet^{-}$. This radical can be transported to phagolysosomes and the extracellular environment and, subsequently, it can be transformed into hydrogen peroxide $\left(\mathrm{H}_{2} \mathrm{O}_{2}\right)$ by SOD or spontaneous dismutation. This compound can be further metabolized by GPx and CAT. ${ }^{8}$

Superoxide dismutase catalyzes the reaction of $\mathrm{O}_{2}{ }^{-}$ dismutation into oxygen and $\mathrm{H}_{2} \mathrm{O}_{2}$. It has been proven that SOD also exhibits enzymatic activity toward other substrates, for example, singlet oxygen. Three isoforms of SOD (SOD-1, SOD-2 and SOD-3) have been distinguished; they differ by the type of cofactor, their sensitivity to inhibitors and their location in the cell. ${ }^{9-11}$

Glutathione peroxidase catalyzes the reduction of $\mathrm{H}_{2} \mathrm{O}_{2}$ and organic peroxides with the use of reduced glutathione. Four isoforms of this enzyme have been distinguished (GPx-1, GPx-2, GPx-3, and GPx-4). In the active center of each type, selenocysteine can be found, an amino acid which enables the 2-electron oxidation of glutathione. ${ }^{9}$ This enzyme plays an important role in the case of low concentrations of $\mathrm{H}_{2} \mathrm{O}_{2}$ in the cell. ${ }^{12,13}$ Salivary peroxidase $(\mathrm{Px})$ can be further distinguished in the environment of the oral cavity. The Px system consists of GPx and myeloperoxidase (MPO), $\mathrm{H}_{2} \mathrm{O}_{2}$, and a thiocyanate ion $\left(\mathrm{SCN}^{-}\right) .{ }^{14,15}$ In the presence of $\mathrm{H}_{2} \mathrm{O}_{2}$, Px oxidizes $\mathrm{SCN}^{-}$, which leads to the formation of bactericidal products, and helps regulate the amount of $\mathrm{H}_{2} \mathrm{O}_{2}$ produced by bacteria and leukocytes (antioxidative activity). Myeloperoxidase, synthetized by neutrophils and monocytes, catalyzes the oxidation of a chloride ion $\left(\mathrm{Cl}^{-}\right)$and the reduction of $\mathrm{H}_{2} \mathrm{O}_{2}$ into hypochlorous acid $(\mathrm{HOCl})$, which forms bactericidal chloramines with amines. ${ }^{14,16}$ Peroxidase is one of the most important antioxidants synthesized by the salivary glands, even though it constitutes only $0.01 \%$ of the total protein content in the saliva. ${ }^{17}$

The activity of CAT is twofold, depending on the concentration of $\mathrm{H}_{2} \mathrm{O}_{2}$ in the cell. At high concentrations of $\mathrm{H}_{2} \mathrm{O}_{2}$, the enzyme catalyzes the reaction of $\mathrm{H}_{2} \mathrm{O}_{2}$ dismutation, which leads to the production of oxygen that is used by the body in metabolic processes. At low concentrations of $\mathrm{H}_{2} \mathrm{O}_{2}$, this enzyme acts as $\mathrm{Px}$, whose activity is related mainly to the deactivation of $\mathrm{H}_{2} \mathrm{O}_{2} \cdot{ }^{12,13}$

The aim of this systematic overview of the literature was to present the current research on the activity of antioxidant enzymes - SOD, GPx and CAT - in the gingival tissue, gingival fluid, saliva, and blood serum of patients with periodontitis. It can serve as the basis for establishing the role of enzymatic antioxidants in the course of periodontitis.

\section{Material and methods}

This systematic overview of the literature was carried out in accordance with the guidelines of the Preferred Reporting Items for Systemic Reviews and Meta-Analyses (PRISMA). ${ }^{18}$

The questions regarding the overview were as follows: - Is there a difference in the activity of SOD, GPx and CAT in the gingival tissue, gingival fluid or in the saliva in relation to the control group?

- In periodontitis, is there a difference in the activity of those enzymes in the blood serum in relation to the control group?

The overview referred to all publications in English, German, Polish, and Russian concerning research on the activity of SOD, GPx and CAT in the course of periodontitis. Only original in vivo human studies were considered; no abstracts, letters to editors, case reports, or review papers were included.

The inclusion criteria were as follows: chronic or aggressive periodontitis (CP or AgP) in generally healthy individuals; and the presence of at least 15 teeth. The following exclusion criteria were adopted: a systemic disease affecting the oxidoreductive balance; nicotinism; periodontal treatment within 6 months prior to the study; pregnancy; or a lack of a control group, defined as healthy periodontium or gingivitis. 
The information was obtained from electronic databases. Electronic selection was carried out in the MEDLINE (PubMed), Scopus and Polish Medical Bibliography databases. Works published before the end of 2018 were included. The following key words were used while searching for the potential papers: periodontitis; periodontal diseases; oxidative stress; enzymatic antioxidants; superoxide dismutase (SOD); glutathione peroxidase (GPx); and catalase (CAT). The articles obtained in that manner were then independently verified by both authors (TK and JT) in terms of the inclusion and exclusion criteria.

In the preliminary selection, abstracts, case reports, review papers, animal studies, in vitro studies, and repeated publications were eliminated. Statistical differences between the activity of SOD, GPx and CAT in the gingival fluid, saliva, blood serum, or gingival tissue between patients with periodontitis (the study group) and individuals with healthy periodontium or gingivitis (the control group) had to be determined for the studies to qualify for the overview.
Both authors (TK and JT) independently obtained the following data from each study: the author, the year of publication, the country of the study, the sample size, the age of the participants, the definition of periodontitis, the method of the biochemical test, the average values of SOD, GPx and CAT in the biological fluids assessed, and the $p$-value along with the type of statistical test carried out.

\section{Results}

The initial overview identified 1,108 items thematically related to the role of oxidative stress in periodontitis. After careful analysis, 19 papers meeting the inclusion criteria were selected. In the final qualification, 4 studies with endpoints different from the adopted ones were excluded. ${ }^{19-22}$ Finally, 11 controlled clinical studies were classified for the overview, ${ }^{23-33}$ along with 4 clinical intervention studies. ${ }^{34-37}$ The process of selecting works for the systematic review is presented in Fig. 1.

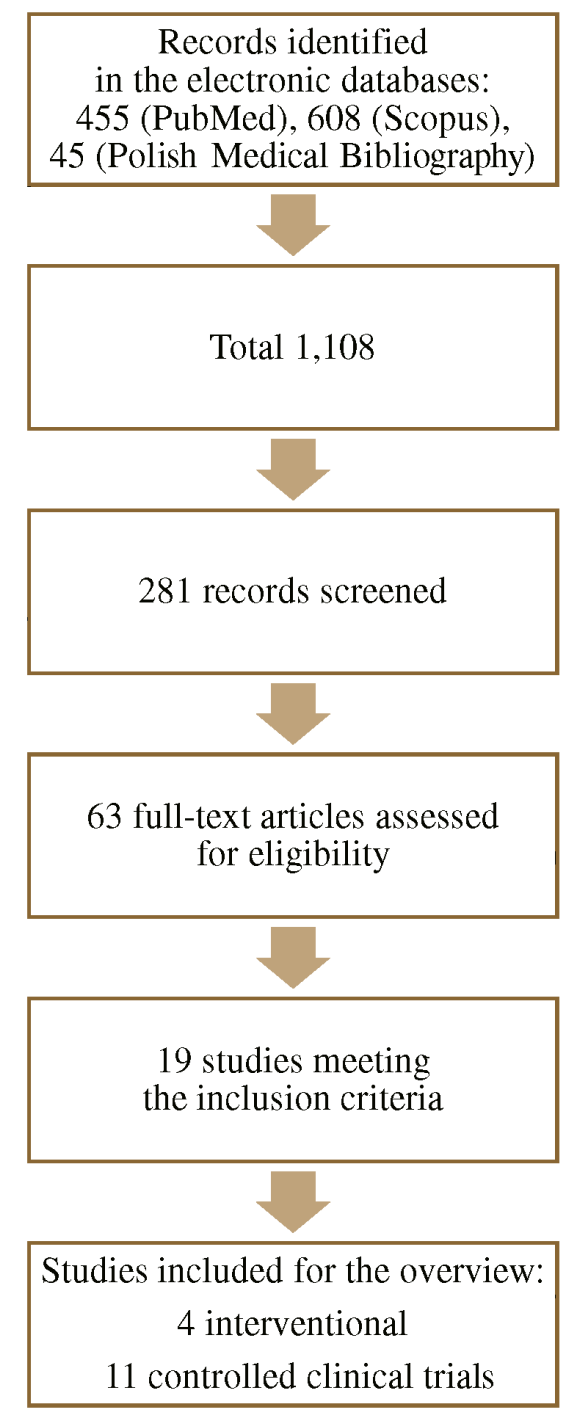

$1^{\text {st }}$ elimination - abstracts, duplicated and nonrelevant titles -827

$2^{\text {nd }}$ elimination - case and review articles, language -218

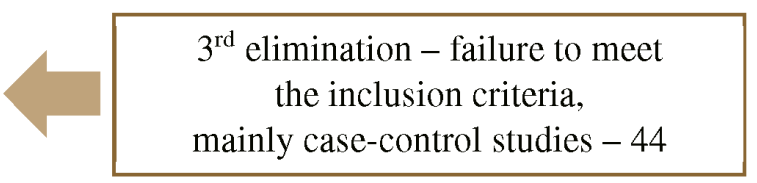

Articles excluded, with reasons no interesting outcome -4

Fig. 1. Flow chart of the study selection process for the systematic review 


\section{Superoxide dismutase}

The qualified studies on the activity of SOD in patients with periodontitis in comparison with a control group are presented in Table 1. Three studies reported a higher activity of SOD in the gingival tissue of patients with periodontitis than in the control group..$^{23,24,35} \mathrm{~A}$ higher SOD activity in the blood serum of patients with periodontitis than in the control group was found in only 1 study, ${ }^{34}$ and a lower activity was observed in as many as 5 studies. ${ }^{23,26,27,30,36}$ The lowest SOD activity was found in the blood serum of patients with AgP. ${ }^{30}$ In 1 study, a higher SOD activity occurred in the saliva of patients with periodontitis in relation to the control group, ${ }^{34}$ and in 2 others it was lower. ${ }^{25,28}$ In 1 paper, a higher activity of SOD was observed in the gingival fluid of patients with periodontitis than in the control group ${ }^{34}$ whereas in 2 other studies it was significantly lower. ${ }^{29,30}$ The lowest activity of SOD was observed in the gingival fluid of patients with AgP. ${ }^{30}$

In 2005, Panjamurthy et al. carried out a study on a group of 25 males with $\mathrm{CP}^{23}$ The control group consisted of 25 males with clinically healthy periodontia. A higher activity of SOD was observed in both the gingival tissue and the blood serum of patients with periodontitis as compared to the control group $(p=0.001){ }^{23}$

Also in 2005, Akalin et al. conducted a study on a group of 26 patients with $\mathrm{CP}$, aged $31-52$, and 18 people with clinically healthy periodontia, aged $22-29 .{ }^{24}$ The activity of SOD in the gingival tissue in the $\mathrm{CP}$ group was significantly higher than in the case of the control group $(p=0.0001)$. Although the experimental group showed a lower SOD activity in the gingival fluid than the control group did, the difference was not statistically significant $(p=0.356){ }^{24}$

Canakci et al. assessed SOD activity in a group of $30 \mathrm{pa}-$ tients (15 males and 15 females), aged 31-63, with CP. ${ }^{25}$ The control group consisted of 30 periodontically healthy patients (15 males and 15 females), aged $27-59$. It was found that SOD activity in the saliva was significantly lower in patients with $\mathrm{CP}$ than in the control group $(p<0.05)$. Additionally, in patients from the experimental group, a significant positive correlation between SOD and GPx was observed. A significant negative correlation between SOD activity in the saliva and the biomarkers of oxidative damage - the 8-OHdG protein and malondialdehyde (MDA) - was also observed. No significant correlations between SOD activity in the saliva and the indicators of the clinical condition of the periodontium were found. ${ }^{25}$

Wei et al. conducted a study on a group of 48 patients (27 males and 21 females), aged $40.1 \pm 7.3$ years, with CP. ${ }^{34}$ The control group consisted of 35 people (19 males and 16 females) with clinically healthy periodontia, aged $42.1 \pm 7.7$ years. The concentrations of SOD were higher in the blood serum, saliva and gingival fluid of patients with CP than in the control group $(p<0.05)$. It was also observed that the highest concentrations occurred in the gingival fluid rather than in the blood or saliva of patients with periodontitis. ${ }^{34}$

Dhotre et al. assessed the activity of SOD in the blood serum of a group of 25 patients with periodontitis. ${ }^{26}$ A lower activity of SOD was observed in this group than in the control group $(p<0.001){ }^{26}$

Sukhtankar et al. studied the activity of SOD in the gingival tissue of 20 patients with CP, aged 24-55, and in 20 individuals with healthy periodontia the same age. ${ }^{35}$ A significantly higher SOD activity was observed in the gingival tissue of patients with periodontitis than in the control group $(p=0.00003){ }^{35}$

Thomas et al. carried out a test for the SOD concentration in the blood serum of patients with periodontitis, patients with gingivitis and individuals with no clinical changes in the periodontium. ${ }^{36}$ It was found that the SOD concentration in the blood serum of individuals with periodontitis and gingivitis were significantly lower $(p<0.001)$ than in the healthy group. ${ }^{36}$

Sreeram et al. assessed the concentration of SOD in the blood serum of a group of 150 patients with periodontitis, aged $41.0 \pm 12.2$ years..$^{27}$ The control group consisted of 150 patients without clinically noticeable changes in the periodontium, aged $34.2 \pm 12.0$ years. A significantly lower activity of SOD was reported in the blood serum of the study group $(p=0.000){ }^{27}$

Trivedi et al. conducted a study on a group of $30 \mathrm{pa}-$ tients with $\mathrm{CP}$, aged $25-45 .^{28}$ The control group consisted of 30 periodontally healthy people, also aged $25-45$. A significantly lower activity of SOD was found in the saliva of patients with periodontitis than in the control group $(p<0.01)$. Moreover, an inverse correlation was proven between salivary SOD activity and the concentration of MDA, a marker of lipid peroxidation. ${ }^{28}$

Ghallab et al. assessed SOD activity in the gingival fluid of 50 patients with periodontitis, broken down into 2 equal groups of $\mathrm{CP}$ and $\mathrm{AgP} .{ }^{29}$ The control group consisted of 15 people with no clinical lesions in the periodontium. The activity of SOD in the gingival fluid was significantly lower in both experimental groups $(p<0.01)$ and it was the lowest in patients with AgP. ${ }^{29}$

Narendra et al. conducted a study on a group of $78 \mathrm{pa}-$ tients with periodontitis, including 32 patients, aged $18-28$, with AgP and 46 patients, aged 30-62, with CP. ${ }^{30}$ Fifty periodontally healthy individuals, aged 20-52, comprised the control group. A significantly lower SOD activity was found in the blood serum and gingival fluid of patients with $\mathrm{AgP}$ and $\mathrm{CP}$ in comparison with the control group $(p<0.001)$. A lower SOD activity was also observed in the blood serum of patients with AgP than in patients with CP $(p<0.001)$. Likewise, a significantly lower SOD activity was found in the gingival fluid of AgP patients as compared to those with CP $(p<0.001){ }^{30}$ 
Table 1. Summary of the activity of superoxide dismutase (SOD) in patients with periodontitis

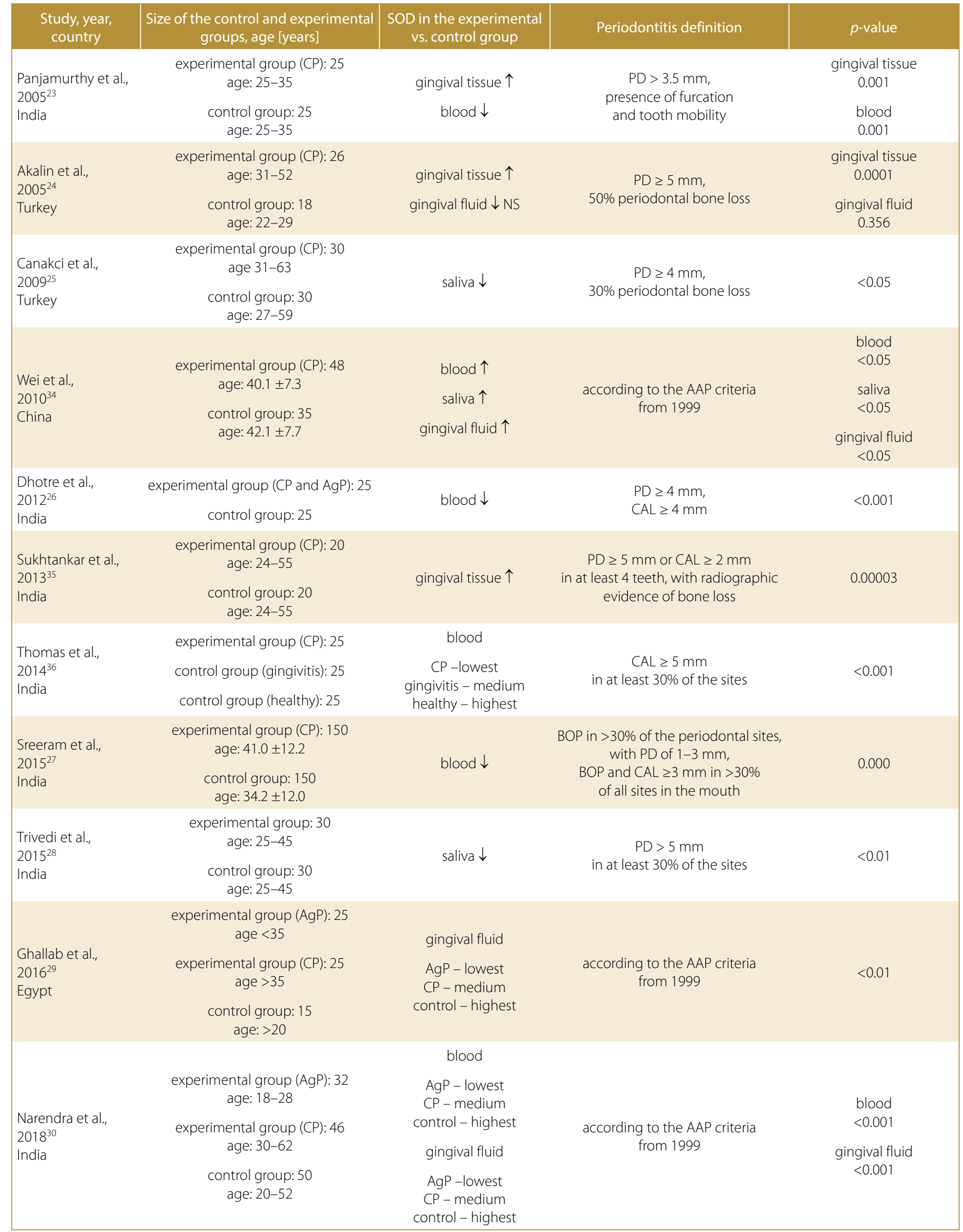

Age presented as range or as mean \pm standard deviation (SD).

CP - chronic periodontitis; AgP - aggressive periodontitis; NS - non-significant; PD - pocket depth; AAP - American Academy of Periodontology; CAL - clinical attachment level; BOP - bleeding on probing; $\uparrow$ - higher; $\downarrow$-lower. 


\section{Glutathione peroxidase}

A summary of the studies on the activity of GPx in patients with periodontitis in comparison with a control group which were selected for this review is presented in Table 2. A higher activity of GPx in the gingival tissue of patients with periodontitis was found in 2 studies. ${ }^{23,32}$ A higher activity of GPx was observed in the blood serum of patients with periodontitis as compared to the control group in 1 study, ${ }^{23}$ and in 2 studies, the observed activity was lower. ${ }^{26,27}$ A statistically insignificantly higher activity of GPx was observed in the saliva of patients with periodontitis in relation to the control group in 1 study, ${ }^{31}$ and in 2 reports, the activity was lower. ${ }^{25,33}$

Panjamurthy et al. observed a higher activity of GPx in both the blood and the gingival tissue of patients with CP as compared to individuals from the control group $(p=0.001){ }^{23}$

Tsai et al. carried out a study on the activity of GPx in the saliva on a group of 21 patients (13 males and 8 females) with CP and 22 patients with clinically healthy periodontia. ${ }^{31}$ No significant differences were observed in the salivary activity of this antioxidant enzyme between the compared groups. ${ }^{31}$

Borges et al. assessed GPx activity in the gingival tissue of 9 individuals with CP, aged $52.9 \pm 5.0$ years, and in 9 individuals with no inflammatory changes in the periodontium, aged $51.1 \pm 9.6$ years. ${ }^{32}$ A significantly higher GPx activity was observed in patients with CP than in the control group $(p=0.006) .^{32}$

Canakci et al. found that the GPx concentration in the saliva was significantly lower in patients with periodontitis than in individuals from the control group. ${ }^{25}$ Moreover, a significant positive correlation was observed between GPx and SOD in patients from the experimental group. A significant negative correlation was also observed between GPx activity in the saliva and the biomarkers of oxidative damage (8-OHdG and MDA) $(p<0.05)$. No significant correlations between GPx activity in the saliva and the indicators of the clinical condition of the periodontium were found. ${ }^{25}$

Dhotre et al. observed a significantly lower SOD activity in the blood serum of patients with periodontitis than in the control group $(p<0.001){ }^{26}$

Miricescu et al. carried out a study on the salivary activity of GPx in a group of 20 patients with CP (5 males and 15 females), aged $51.26 \pm 7.40$ years. ${ }^{33}$ Twenty individuals with no clinical lesions in the periodontium were selected for the control group. The activity of GPx in the saliva of patients with periodontitis was significantly lower than in the control group $(p<0.05) .^{33}$

Sreeram et al. observed that GPx activity in the blood serum of patients with periodontitis was significantly lower than in the case of the control group $(p=0.000) .{ }^{27}$

Table 2. Summary of the activity of glutathione peroxidase (GPx) in patients with periodontitis

\begin{tabular}{|c|c|c|c|c|}
\hline $\begin{array}{l}\text { Study, year, } \\
\text { country }\end{array}$ & $\begin{array}{c}\text { Size of the control and experimental } \\
\text { groups, age [years] }\end{array}$ & $\begin{array}{l}\text { GPx in the experimental } \\
\text { vs. control group }\end{array}$ & Periodontitis definition & $p$-value \\
\hline $\begin{array}{l}\text { Panjamurthy et al., } \\
2005^{23} \\
\text { India }\end{array}$ & $\begin{array}{l}\text { experimental group }(\mathrm{CP}): 25 \\
\text { age: } 25-35 \\
\text { control group: } 25 \\
\text { age: } 25-35\end{array}$ & $\begin{array}{l}\text { gingival tissue } \uparrow \\
\text { blood } \uparrow\end{array}$ & $\begin{array}{l}\text { PD }>3.5 \mathrm{~mm} \\
\text { presence of furcation } \\
\text { and tooth mobility }\end{array}$ & $\begin{array}{c}\text { gingival tissue } \\
0.001 \\
\text { blood } \\
0.001\end{array}$ \\
\hline $\begin{array}{l}\text { Tsai et al., } \\
2005^{31} \\
\text { Taiwan }\end{array}$ & $\begin{array}{l}\text { experimental group }(\mathrm{CP}): 21 \\
\text { control group: } 22\end{array}$ & saliva $\uparrow N S$ & not specified & $>0.05$ \\
\hline $\begin{array}{l}\text { Borges et al., } \\
2007^{32} \\
\text { Brazil }\end{array}$ & $\begin{array}{c}\text { experimental group (CP): } 9 \\
\text { age } 52.9 \pm 5.0 \\
\text { control group: } 9 \\
\text { age: } 51.1 \pm 9.6\end{array}$ & gingival tissue $\uparrow$ & $\begin{array}{l}P D \geq 5 \mathrm{~mm} \\
C A L \geq 3 \mathrm{~mm}\end{array}$ & 0.006 \\
\hline $\begin{array}{l}\text { Canakci et al., } \\
2009^{25} \\
\text { Turkey }\end{array}$ & $\begin{array}{c}\text { experimental group (CP): } 30 \\
\text { age } 31-63 \\
\text { control group: } 30 \\
\text { age: } 27-59\end{array}$ & saliva $\downarrow$ & $\begin{array}{c}\mathrm{PD} \geq 4 \mathrm{~mm} \text {, } \\
30 \% \text { periodontal bone loss }\end{array}$ & $<0.05$ \\
\hline $\begin{array}{l}\text { Dhotre et al., } \\
2012^{26} \\
\text { India }\end{array}$ & $\begin{array}{l}\text { experimental group (CP and AgP): } 25 \\
\text { control group: } 25\end{array}$ & blood $\downarrow$ & $\begin{array}{l}\mathrm{PD} \geq 4 \mathrm{~mm} \\
\mathrm{CAL} \geq 4 \mathrm{~mm}\end{array}$ & $<0.001$ \\
\hline $\begin{array}{l}\text { Miricescu et al., } \\
2014^{33} \\
\text { Romania }\end{array}$ & $\begin{array}{l}\text { experimental group (CP): } 20 \\
\text { age: } 51.26 \pm 7.40 \\
\text { control group: } 20\end{array}$ & saliva $\downarrow$ & $\begin{array}{c}\mathrm{PD} \geq 4 \mathrm{~mm} \\
>30 \% \text { periodontal bone loss }\end{array}$ & $<0.05$ \\
\hline $\begin{array}{l}\text { Sreeram et al., } \\
2015^{27} \\
\text { India }\end{array}$ & $\begin{array}{c}\text { experimental group (CP): } 150 \\
\text { age: } 41.0 \pm 12.2 \\
\text { control group: } 150 \\
\text { age: } 34.2 \pm 12.0\end{array}$ & blood $\downarrow$ & $\begin{array}{l}\text { BOP in }>30 \% \text { of the periodontal sites, } \\
\text { with PD of } 1-3 \mathrm{~mm} \text {, } \\
\text { BOP and CAL } \geq 3 \mathrm{~mm} \text { in }>30 \% \text { of all } \\
\text { sites in the mouth }\end{array}$ & 0.000 \\
\hline
\end{tabular}

Age presented as range or as mean \pm standard deviation (SD). 


\section{Catalase}

Table 3 presents a summary of CAT activity in patients with periodontitis in comparison with a control group based on the studies which qualified for this review. A higher CAT activity was observed in the gingival tissue of patients with periodontitis in 1 study and the result was statistically significant. ${ }^{23}$ A higher CAT activity was found in the blood serum of patients with periodontitis as compared to the control group in 1 study, ${ }^{23}$ whereas in another study it was lower. ${ }^{37}$ A statistically significant lower CAT activity was observed in the saliva of patients with periodontitis than in those from the control group in 1 study. ${ }^{28}$

Panjamurthy et al. observed a significantly higher CAT activity in both the blood and the gingival tissue of patients with periodontitis as compared to individuals from the control group $(p=0.0001) .{ }^{23}$

Borges et al. did not observe any significant difference in CAT activity in the gingival tissue of the experimental group in comparison with the control group $(p=0.523) .^{32}$

Thomas et al. carried out a study on CAT activity in 25 patients with periodontitis, 25 patients with gingivitis and 25 periodontally healthy individuals. ${ }^{37}$ They showed a significantly lower CAT activity in the blood serum of patients with periodontitis than in patients with gingivitis and individuals with no inflammatory lesions in the periodontium $(p<0.001) .{ }^{37}$

Trivedi et al. reported a lower CAT activity in the saliva of patients with periodontitis than in the control group $(p<0.001){ }^{28}$ A negative correlation between CAT activity and the MDA concentration was also observed. ${ }^{28}$

\section{Conclusions}

Antioxidant enzymes, such as SOD, GPx or CAT, protect the structural and tissue integrity by preventing the harmful activity of oxygen-free radicals. An imbalance between the production of oxygen-free radicals and antioxidative mechanisms plays an important role in the etiopathogenesis of periodontitis. The activity of enzymatic antioxidants varies greatly in the course of periodontitis, especially in the gingival fluid and saliva. In the gingival tissue and blood serum, their activity is usually higher. These differences may result from the initial mobilization of the antioxidative reserves, which leads to an increase in the activity of antioxidant enzymes. Another probable explanation is a pathological increase in neutrophil activity and the oxidative burst of PMNs. Even with the nominal activity of antioxidant enzymes, the oxidoreductive balance is disturbed. Thus, the varied advancement of periodontitis is reflected by the activity of the enzymatic antioxidants. It is possible that the current classification of the advancement and progression risk of periodontitis created by Page and Eke insufficiently translates into the tissue, salivary and serum activity of those antioxidative factors. Due to a small number of studies and the small sample sizes of the study groups, it was not possible to carry out a meta-analysis. Significant limitations of the studies that have been carried out so far include very diverse methodologies of the biochemical analyses (antioxidant activity expressed in different units, which makes it difficult to combine studies in a meta-analysis), very diverse definitions of periodontitis, failure to assess the influence of the duration of periodontitis, and incomplete eradication of local and general factors, which may affect the antioxidant activity under study.

Table 3. Summary of the activity of catalase (CAT) in patients with periodontitis

\begin{tabular}{|c|c|c|c|c|}
\hline $\begin{array}{l}\text { Study, year, } \\
\text { country }\end{array}$ & $\begin{array}{c}\text { Size of the control and experimental } \\
\text { groups, age [years] }\end{array}$ & $\begin{array}{l}\text { CAT in the experimental } \\
\text { vs. control group }\end{array}$ & Periodontitis definition & $p$-value \\
\hline $\begin{array}{l}\text { Panjamurthy et al., } \\
2005^{23} \\
\text { India }\end{array}$ & $\begin{array}{c}\text { experimental group (CP): } 25 \\
\text { age: } 25-35 \\
\text { control group: } 25 \\
\text { age: } 25-35\end{array}$ & $\begin{array}{l}\text { gingival tissue } \uparrow \\
\text { blood } \uparrow\end{array}$ & $\begin{array}{c}\mathrm{PD}>3.5 \mathrm{~mm}, \\
\text { presence of furcation and tooth } \\
\text { mobility }\end{array}$ & $\begin{array}{c}\text { gingival tissue } \\
0.001 \\
\text { blood } \\
0.001\end{array}$ \\
\hline $\begin{array}{l}\text { Borges et al., } \\
2007^{32} \\
\text { Brazil }\end{array}$ & $\begin{array}{c}\text { experimental group (CP): } 9 \\
\text { age } 52.9 \pm 5.0 \\
\text { control group: } 9 \\
\text { age: } 51.1 \pm 9.6\end{array}$ & gingival tissue NS & $\begin{array}{l}\mathrm{PD} \geq 5 \mathrm{~mm} \\
\mathrm{CAL} \geq 3 \mathrm{~mm}\end{array}$ & 0.523 \\
\hline $\begin{array}{l}\text { Thomas et al., } \\
2014^{37} \\
\text { India }\end{array}$ & $\begin{array}{l}\text { experimental group (CP): } 25 \\
\text { control group (gingivitis): } 25 \\
\text { control group (healthy): } 25\end{array}$ & $\begin{array}{c}\text { blood } \\
\text { CP -lowest } \\
\text { gingivitis - medium } \\
\text { healthy-highest }\end{array}$ & $\begin{array}{l}\qquad \mathrm{CAL} \geq 5 \mathrm{~mm} \\
\text { in at least } 30 \% \text { of the sites }\end{array}$ & $<0.001$ \\
\hline $\begin{array}{l}\text { Trivedi et al., } \\
2015^{28} \\
\text { India }\end{array}$ & $\begin{array}{l}\text { experimental group: } 30 \\
\text { age: } 25-45 \\
\text { control group: } 30 \\
\text { age: } 25-45\end{array}$ & saliva $\downarrow$ & $\begin{array}{l}\qquad \mathrm{PD}>5 \mathrm{~mm} \\
\text { in at least } 30 \% \text { of the sites }\end{array}$ & $<0.001$ \\
\hline
\end{tabular}

Age presented as range or as mean \pm standard deviation (SD). 
Further studies aimed at explaining the role of oxidative stress in the occurrence and course of periodontitis are undoubtedly necessary. The inclusion and exclusion criteria should be unified, as they may affect differences in the results between authors. Perhaps the new classification of periodontitis created during the World Workshop on the Classification of Periodontal and Peri-implant Diseases and Conditions will be linked to the local and/or general activity of the enzymatic antioxidants in a better and more homogeneous way. These studies may have important therapeutic implications in the local use of antioxidants in periodontitis treatment.

\section{ORCID iDs}

Joanna Toczewska (1) https://orcid.org/0000-0002-7906-639X

Tomasz Konopka (10 https://orcid.org/0000-0003-3042-4712

\section{References}

1. Lushchak VI. Classification of oxidative stress based on its intensity. EXCLI J. 2014;13:922-937.

2. Moseley R, Waddington RJ, Embery G, Rees SG. The modification of alveolar bone proteoglycans by reactive oxygen species in vitro. Connect Tissue Res. 1998;37(1-2):13-28.

3. Chapple IL. Reactive oxygen species and antioxidants in inflammatory diseases. J Clin Periodontol. 1997;24(5):287-296.

4. Jarnbring F, Somogyi E, Dalton J, Gustafsson A, Klinge B. Quantitative assessment of apoptotic and proliferative gingival keratinocytes in oral and sulcular epithelium in patients with gingivitis and periodontitis. J Clin Periodontol. 2002;29(12):1065-1071.

5. Liu Z, Liu Y, Song Y, Zhang X, Wang S, Wang Z. Systemic oxidative stress biomarkers in chronic periodontitis: A meta-analysis. Dis Markers. 2014;2014:931083.

6. Kimura S, Yonemura T, Kaya H. Increased oxidative product formation by peripheral blood polymorphonuclear leukocytes in human periodontal diseases. J Periodontal Res. 1993;28(3):197-203.

7. Chapple IL, Matthews JB. The role of reactive oxygen and antioxidant species in periodontal tissue destruction. Periodontol 2000. 2007;43:160-232.

8. Wang Y, Andrukhov O, Rausch-Fan X. Oxidative stress and antioxidant system in periodontitis. Front Physiol. 2017;8:910.

9. Bartold PM, Van Dyke TE. Periodontitis: A host-mediated disruption of microbial homeostasis. Unlearning learned concepts. Periodontol 2000. 2013;62(1):203-217.

10. Gruber B. Antioxidant enzymes protecting the organism against reactive oxygen species [in Polish]. Farm Pol. 1996;52:263-271.

11. de Groot H, Hegi U, Sies H. Loss of alpha-tocopherol upon exposure to nitric oxide or the sydnonimine SIN-1. FEBS Lett. 1993;315(2):139-142.

12. Carpena $X$, Wiseman B, Deemagarn T, et al. A molecular switch and electronic circuit modulate catalase activity in catalase-peroxidases. EMBO Rep. 2005;6(12):1156-1162.

13. Switala J, Loewen PC. Diversity of properties among catalases. Arch Biochem Biophys. 2002;401(2):145-154.

14. Battino M, Ferreiro MS, Gallardo I, Newman HN, Bullon P. The antioxidant capacity of saliva. J Clin Periodontol. 2002;29(3):189-194.

15. Kanehira T, Shibata K, Kashiwazaki H, Inoue N, Morita M. Comparison of antioxidant enzymes in saliva of elderly smokers and nonsmokers. Gerodontology. 2006;23(1):38-42.

16. Tenovuo J, Pruitt KM. Relationship of the human salivary peroxidase system to oral health. J Oral Pathol. 1984;13(6):573-584.

17. Taylor SI, Barr V, Reitman M. Does leptin contribute to diabetes caused by obesity. Science. 1996;274(5290):1151-1152.

18. Moher D, Liberati A, Tetzlaff J, Altman DG; PRISMA group. Preferred reporting items for systematic reviews and meta-analyses: The PRISMA statement. Int J Surg. 2010;8(5):336-341.

19. Sree SL, Sethupathy S. Evaluation of the efficacy of taurine as an antioxidant in the management of patients with chronic periodontitis. Dent Res J (Isfahan). 2014;11(2):228-233.
20. Lee CY, Choy CS, Lai YC, et al. A cross-sectional study of endogenous antioxidants and patterns of dental visits of periodontitis patients. Int J Environ Res Public Health. 2019;16(2):E180.

21. Kim SC, Kim OS, Kim OJ, Kim YJ, Chung HJ. Antioxidant profile of whole saliva after scaling and root planning in periodontal disease. J Periodontal Implant Sci. 2010;40(4):164-171.

22. Novakovic N, Todorovic T, Rakic M, et al. Salivary antioxidants as periodontal biomarkers in evaluation of tissue status and treatment outcome. J Periodontal Res. 2014;49(1):129-136.

23. Panjamurthy K, Manoharan S, Ramachandran CR. Lipid peroxidation and antioxidant status in patients with periodontitis. Cell Mol Biol Lett. 2005;10(2):255-264.

24. Akalin FA, Toklu E, Renda N. Analysis of superoxide dismutase activity levels in gingiva and gingival crevicular fluid in patients with chronic periodontitis and periodontally healthy controls. J Clin Periodontol. 2005;32(3):238-243.

25. Canakci CF, Cicek Y, Yildirim A, Sezer U, Canakci V. Increased levels of 8-hydroxydeoxyguanosine and malondialdehyde and its relationship with antioxidant enzymes in saliva of periodontitis patients. Eur J Dent. 2009;3(2):100-106.

26. Dhotre PS, Suryakar AN, Bhogade RB. Oxidative stress in periodontitis. Eur J Gen Med. 2012;9(2):81-84.

27. Sreeram M, Suryakar AN, Dani NH. Is gamma-glutamyl transpeptidase a biomarker for oxidative stress in periodontitis? J Indian Soc Periodontol. 2015;19(2):150-154.

28. Trivedi S, Lal N, Mahdi AA, Singh B, Pandey S. Association of salivary lipid peroxidation levels, antioxidant enzymes, and chronic periodontitis. Int J Periodontics Restorative Dent. 2015;35(2):e14-e19.

29. Ghallab NA, Hamdy E, Shaker OG. Malondialdehyde, superoxide dismutase and melatonin levels in gingival crevicular fluid of aggressive and chronic periodontitis patients. Aust Dent J. 2016;61(1):53-61.

30. Narendra S, Das UK, Tripathy SK, Sahani NC. Superoxide dismutase, uric acid, total antioxidant status, and lipid peroxidation assay in chronic and aggressive periodontitis patients. J Contemp Dent Pract. 2018;19(7):874-880.

31. Tsai CC, Chen HS, Chen SL, et al. Lipid peroxidation: A possible role in the induction and progression of chronic periodontitis. $J$ Periodontal Res. 2005;40(5):378-384.

32. Borges I Jr, Moreira EA, Filho DW, de Oliveira TB, da Silva MB, Fröde TS. Proinflammatory and oxidative stress markers in patients with periodontal disease. Mediators Inflamm. 2007;2007:45794.

33. Miricescu D, Totan A, Calenic B, et al. Salivary biomarkers: Relationship between oxidative stress and alveolar bone loss in chronic periodontitis. Acta Odontol Scand. 2014;72(1):42-47.

34. Wei D, Zhang XL, Wang YZ, Yang CX, Chen G. Lipid peroxidation levels, total oxidant status and superoxide dismutase in serum, saliva and gingival crevicular fluid in chronic periodontitis patients before and after periodontal therapy. Aust Dent J. 2010;55(1):70-78.

35. Sukhtankar L, Kulloli A, Kathariya R, Shetty S. Effect of non-surgical periodontal therapy on superoxide dismutase levels in gingival tissues of chronic periodontitis patients: A clinical and spectophotometric analysis. Dis Markers. 2013;34(5):305-311.

36. Thomas B, Shabeer MM, Amitha R, Rajendra BP, Suchetha K. Comparative evaluation of serum superoxide dismutase and glutathione levels in periodontally diseased patients: An interventional study. Indian J Dent Res. 2014;25(5):613-616.

37. Thomas B, Madani SM, Prasad BR, Kumari S. Comparative evaluation of serum antioxidant levels in periodontally diseased patients: An interventional study. Contemp Clin Dent. 2014;5(3):340-344. 